\title{
Main Factors Affecting the Online Service Satisfaction-an Empirical Study in China
}

\author{
YanJu Li \\ HeNan University of Animal Husbandry and Economy \\ No.2 of YingCai Road, ZhengZhou, HeNan, China \\ liyanju69@126.com
}

\begin{abstract}
Online service quality has a significant influence on many important aspects of electronic commerce (e-commerce). However, there are few quantitative studies on the investrgation of the main affecting factors of the online service quality focused on the market im China, which is one of the developing countries with the highest online population grow h. This paper is an attempt to identify the main factors affecting the online service satisfaction of the e-commerce websites in China, and Fisher's exact test is applied to identify the main affecting factors of online service satisfaction. The results could be the guideline for the e-commerce companies in terms of improving their online service.
\end{abstract}

Keywords: online service, Fisher's exact test, empirical study, China

\section{Introduction}

As the development of the internet, there areincreasingly users in the world engaging in ecommerce activities. As the biggest developing country, China has the highest online population growth rates in terms of online shopping. The online service quality is becoming increasing important as the e-commetce companies deliver an expanding array of services through the internet, in which the websites clearly emerge as a critical channel for ecommerce companies, Online service quality has a significant influence on many aspects of the e-commerce, which inclade the consumer trust on the e-commerce companies (Gefen, 2002; Hwang and Kim, 2007, Hsu, 2008); attitude toward e-shopping (Ha and Stoel, 2009); willingness to pay more (Lee and Lin, 2005; Cristobal et al., 2007; Ho and Lee, 2007); site loyalty intentions (Ho and Lee, 2007; Yoo and Donthu, 2001); user online satisfaction (Lee and Lin, 2005; Cristobal et al., 2007; Ho and Lee, 2007). Online e-service has been increasingly recognized as the most important determinant of long-term performance and success for online retailers (Zeithaml et al., 2002; Santos, 2003; Wolfinbarger and Gilly, 2003; Holloway and Beatty, 2003; Fassnacht and Koese, 2005).

It is necessary for the e-commerce companies to identify customers' needs, wants, and preferences in order to deliver high quality service performance (Howard and Worboys, 2003). However, the service environment differs a lot between the physical stores and online storefronts, so it is necessary to study the main factors affecting the online service satisfaction of the e-commerce websites.

This paper is an attempt to identify the main factors affecting online service quality for the e-commerce companies in China, which could be the guideline for the development of the companies. The remainder of this study is organized as follows. Section 2 introduces the related literature about the online service quality. Following is a brief introduction about the Fisher's exact test which is employed in this research. Section 4 discusses the main factors 
that have an impact on the online service in China. In the last section, the related managerial implications of this research are discussed.

\section{Literature Review}

The perceived online service quality and satisfaction are two main characters which are used by consumers to evaluate e-commerce companies' quality. Service quality remains of focal interest to researchers and practitioners. Some researchers consider the delivered service that meet the customer's expectation is the key point. The e-service quality research is still in a primary condition compared with the face-to-face services (Serkan et al., 2010).

A series of researches about web site quality measurement (Loiacono et al., 2002; Yoo and Donthu, 2001), online service quality evaluation (Bauer et al., 2006; Parasuraman et al., 2005; Zeithaml et al., 2000), or e-retailing quality appraisal (Wolfinbarger and Gilly 2003) are studied in the related researches. In general, these results derive from rigorous deveropment efforts and focus on important characteristics pertaining to information or he system; few consider the service dimension of online services comprehensively (Nelsonet al., 2005; Wixom and Todd, 2005). Table 1 summarizes the related research results:

Table 1. Online Service Quality Scales in Prior Related Research

\begin{tabular}{|c|c|c|}
\hline Article & System related & Service related \\
\hline $\begin{array}{l}\text { Zeithaml et al. } \\
\text { (2000) }\end{array}$ & $\begin{array}{l}\text { Access, ease of navigation, flexibility, reliability, price } \\
\text { knowledge, aesthetics, efficiency, personalization, } \\
\text { privacy. }\end{array}$ & $\begin{array}{l}\text { Responsiveness, } \\
\text { assurance }\end{array}$ \\
\hline $\begin{array}{l}\text { Francis and } \\
\text { White (2002) } \\
\text { Loiacono et al. } \\
(2002)\end{array}$ & $\begin{array}{l}\text { Product attribute, functionality, ownership conditions, } \\
\text { security } \\
\text { Appeal, response time, flow, image, operations, better } \\
\text { than alternatives, innovativeness, interactivity, trust }\end{array}$ & $\begin{array}{l}\text { Delivery, customer } \\
\text { service }\end{array}$ \\
\hline $\begin{array}{l}\text { Barnes \& } \\
\text { Vidgen (2002) }\end{array}$ & & Empathy, trust \\
\hline $\begin{array}{l}\text { Wolfinbarger \& } \\
\text { Gilly (2003) } \\
\text { Parasuraman et } \\
\text { al. (2005) }\end{array}$ & ability, privacy & $\begin{array}{l}\text { Fulfillment/reliability, } \\
\text { customer service } \\
\text { Fulfillment }\end{array}$ \\
\hline $\begin{array}{l}\text { Parasurama } \\
\text { al. (2005) }\end{array}$ & & $\begin{array}{l}\text { Compensation, } \\
\text { responsiveness } \\
\text { contract }\end{array}$ \\
\hline $\begin{array}{l}\text { Bauer et al. } \\
(2006)\end{array}$ & unctionality/design & $\begin{array}{l}\text { Responsiveness, } \\
\text { enjoyment }\end{array}$ \\
\hline $\begin{array}{l}\text { Yoo \& Donthu } \\
(2001)\end{array}$ & Ease of use, aesthetic design, reliability, tangibles & Responsiveness \\
\hline $\begin{array}{l}\text { Aldwani \& } \\
\text { Palvia (2002) }\end{array}$ & $\begin{array}{l}\text { Technical adequacy, specific content, content quality, } \\
\text { web appearance }\end{array}$ & \\
\hline $\begin{array}{l}\text { Janda etal. } \\
(2002)\end{array}$ & Access, security, information & Sensation \\
\hline $\begin{array}{l}\text { Ranganathan \& } \\
\text { Ganapathy } \\
\text { (2002) }\end{array}$ & Information content, design, security, privacy & \\
\hline $\begin{array}{l}\text { Yang \& Jun } \\
(2002)\end{array}$ & $\begin{array}{l}\text { Reliability, access, ease of use, personalization, } \\
\text { security }\end{array}$ & Responsiveness \\
\hline $\begin{array}{l}\text { Cai \& Jun } \\
(2003)\end{array}$ & Website design/content & $\begin{array}{l}\text { Trustworthiness, } \\
\text { prompt/reliable } \\
\text { service, }\end{array}$ \\
\hline
\end{tabular}


Gounaris \&

Dimitriadis

(2003)

Jun et al. (2004)

Kim \& Stoel

(2004)

Lee \& Lin

(2005)

Parasuraman et

al. (2005)

Yang et al.

(2005)

Collier and

Bienstock

(2006)

Ibrahim et al.

(2006)

Cristobal et al.

(2007)

Ho \& Lee

(2007)

Sohn \&

Tadisina (2008)

Wang et al.

(2010)

Ding et al.

(2011)
Ease of use, attentiveness, access, security, credibility

Web appearance, entertainment, information fit-totask, transaction capacity

Website design, reliability, personalization

Efficiency, system availability, privacy

Usability, usefulness of content, adequacy of information, accessibility

Functionality, information accuracy, design, privacy, ease of use, order condition, order accuracy , procedural fairness, outcome fairness Convenience/accuracy, accessibility/reliability, good queue management, personalization

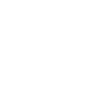

communication

Customer care and risk reduction benefit, information benefit, interaction facilitation Reliable/prompt responses Response time, trust

Responsiveness, trust

Fulfillment

Interaction

Timeliness

interactive fairness

Friendly/responsive

customer service, targeted customer

service

Customer service

Customer relationships, responsiveness Customized communication, speed of delivery

Responsiveness, satisfaction Service convenience, customer service, fulfillment

\section{Methodology}

Fisher's exact test was first proposed in 1992 (Fisher, 1922). It is a statistical significance test in the analysis of contingency tables, and is suitable for the analysis when some of the frequencies are low and use of the chi-squared test is ruled out (i.e. some expected values are 0 or less than twenty percents are less than 5). Fisher's exact test is one of a class of exact tests because the significance of the deviation from a null hypothesis can be calculated exactly rather than relying on an approximation that becomes exact in the limit as the sample size grows to infinity, as with many statistical tests.

The following is an example to illustrate the theory of the fisher's exact test: a sample of teenagers might be divided into male and female on the one hand, and those that are and are not currently dieting on the other. The hypothesis is that the proportion of dieting individuals is higher among the women than the men, and whether any difference of proportions is significant is tested, and the data is shown as follows: 
Table 2. The $2 \star 2$ Contingency Table for the Sample

\begin{tabular}{|l|l|l|l|}
\hline & Men & Women & Row total \\
\hline Dieting & 1 & 9 & 10 \\
\hline Non-dieting & 11 & 3 & 14 \\
\hline Column total & 12 & 12 & 24 \\
\hline
\end{tabular}

These data would not be suitable for analysis by Pearson's chi-squared test, because the expected values in the table are all below 10 , and in a $2 * 2$ contingency table, the number of degrees of freedom is always 1 .

Before we proceed with the Fisher's exact test, we first introduce some notation. We represent the cells by the letters $\mathrm{a}, \mathrm{b}, \mathrm{c}$ and $\mathrm{d}$, call the totals across rows and columns marginal totals, and represent the grand total by n:

Table 3. The $2 * 2$ Contingency Table for the Sample with the Representative Letters

\begin{tabular}{|l|l|l|l|}
\hline & Men & Women & Row total \\
\hline Dieting & $a$ & $b$ & $a+b$ \\
\hline Non-dieting & $c$ & $d$ & $c+d$ \\
\hline Column total & $a+c$ & $b+d$ & $a+b+c+d=n$ \\
\hline
\end{tabular}

The probability of obtaining any such set of values was given by the hypergeometric distribution:

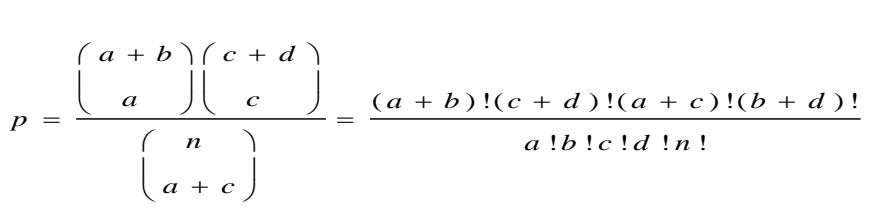

Where $\left(\begin{array}{l}n \\ k\end{array}\right)$ is the binomial coefficient and the symbol ! indicates the factorial operator.

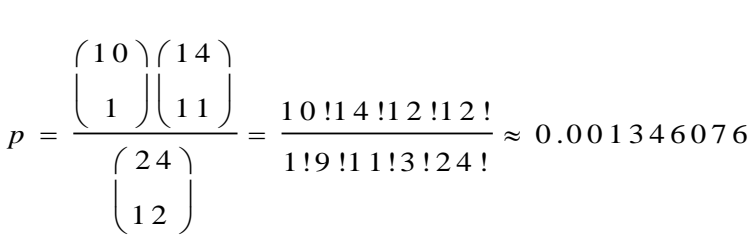

The formula above gives the exact hypergeometric probability of observing this particular arrangement of the data, assuming the given marginal totals, on the null hypothesis that men and women are equally likely to be dieters. To put it another way, if we assume that the probability that a man is a dieter is $\mathrm{p}$, the probability that a woman is a dieter is $p$, and it is assumed that both men and women enter our sample independently of whether or not they are dieters, then this hypergeometric formula gives the conditional probability of observing the values $\mathrm{a}, \mathrm{b}, \mathrm{c}, \mathrm{d}$ in the four cells, conditionally on the observed marginals. This remains true even if men enter our sample with different probabilities than women. The requirement is merely that the two classification characteristics: gender and dieter are not associated.

For example, suppose we knew probabilities $P, Q, p, q$ with $P+Q=p+q=1$ such that (male dieter, male non-dieter, female dieter, female non-dieter) had respective probabilities $(P p, P q, Q p, Q q)$ for each individual encountered under our sampling procedure. The next 
step is to calculate the exact probability of any arrangement of these teenagers into the four cells of the table, but Fisher's exact test showed that to generate a significance level, we need consider only the cases where the marginal totals are the same as in the observed table, and among those, only the cases where the arrangement is as extreme as the observed arrangement, or more so. In this example, there are 11 such cases. Of these only one is more extreme in the same direction as our data:

\section{Table 4. The $2^{\star} 2$ Contingency Table for the Sample Considering the Marginal Totals}

\begin{tabular}{|l|l|l|l|}
\hline & Men & Women & Row total \\
\hline Dieting & 0 & 10 & 10 \\
\hline Non-dieting & 12 & 2 & 14 \\
\hline Column total & 12 & 12 & 24 \\
\hline
\end{tabular}
So the probability is $p=\frac{\left(\begin{array}{c}10 \\
0\end{array}\right)\left(\begin{array}{l}1 \\
12\end{array}\right)}{\left(\begin{array}{l}24 \\
12\end{array}\right)} \approx 0.000033652$

In order to calculate the significance of the observed data, i.e the total probability of observing data as extreme or more extreme if the null hypothesis is true, we have to calculate the values of $p$ for both these tables, and ad them together. This gives a one-tailed test, with $p$ approximately $0.001346076+0.000033652=0.001379728$. This value can be interpreted as the sum of evidence provided by the observed data for the null hypothesis (that there is no difference in the proportions of diefers between men and women). The smaller the value of $p$, the greater the evidence for rejecting the nuil hypothesis; so here the evidence is strong that men and women are not equally likely to be dieters.

For a two-tailed test we must also consider tables that are equally extreme, but in the opposite direction. An approach used by the Fisher' exact test is to compute the $p$-value by summing the probabilities for all tables with probabilities less than or equal to that of the observed table. In the example here, the 2-sided p-value is twice the 1-sided value-but in general these can differ substantially for tables with small counts, unlike the case with test statistics that have a symrnetyic sampling distribution.

\section{Data Collection and Results Analysis}

\subsection{Question naire Design}

The specific factors that may have high influence on the online service satisfaction are listed in Table 5. The questionnaire is designed based on these factors, and the respondents are required to evaluate the related situations based on Five-point scale method (1 indicates the worst evaluations, while 5 indicates the best evaluation). 


\section{Table 5. The Factors may have High Influence on the Online Service Satisfaction}

\begin{tabular}{|c|l|l|}
\hline Goal & \multicolumn{1}{|c|}{ Aspects } & Criteria \\
\hline & & $C_{1}$ Efficiency \\
& & $C_{2}$ Ease of navigation \\
& & $C_{3}$ Flexibility \\
The factors & & $C_{4}$ Reliability \\
may have & $A_{1}$ System related & $C_{5}$ Price knowledge \\
high & & $C_{6}$ Aesthetics \\
influence & & $C_{7}$ Personalization \\
on the & & $C_{8}$ Ownership conditions \\
online & & $C_{9}$ Ease of use \\
service & & $C_{10}$ Speed \\
\cline { 2 - 3 } quality & & $C_{11}$ Responsiveness \\
& & $C_{12}$ Assurance \\
& & $A_{2}$ Service related \\
& & $C_{13}$ Delivery \\
\hline
\end{tabular}

Considering the differences among $\mathrm{B} 2 \mathrm{C}, \mathrm{C} 2 \mathrm{C}$ and $\mathrm{B} 2 \mathrm{~B}$ e-commerce, and our research is focus on $\mathrm{B} 2 \mathrm{C}$ e-commerce websites in China, the $18 \mathrm{~B} 2 \mathrm{C}$-commerce websites in retail market shown in table 6 are selected based on the user coverage

Table 6. 18 B2C e-commerce Websites Retail Market in China

\begin{tabular}{llc}
\hline No. & E-Commerce Website & No. of users (per million) \\
\hline 1 & Tmall & 9010 \\
2 & Jingdong Mall & 6940 \\
3 & Tencent & 3930 \\
4 & Amazon & 3450 \\
5 & Handle group buying & 2580 \\
6 & Dangdang & 2160 \\
7 & Vancl & 2160 \\
8 & Full King & 1290 \\
9 & No.1 & 1050 \\
10 & F groupbuying & 770 \\
11 & Yxun & 760 \\
12 & Moonbasa & 700 \\
13 & Letao & 640 \\
14 & Newegg & 600 \\
15 & M 18 & 570 \\
16 & Ok buy & 560 \\
17 & VIP shop & 490 \\
18 & M baobao & 450 \\
& & \\
\hline
\end{tabular}

The respondents are required to identify 1-5 e-commerce websites that they are most familiar with and evaluate the related aspects in terms of the e-service quality. In this survey, 50 questionnaires were sent out, 48 were returned and 40 were valid. 


\subsection{Internal Consistency Test}

In statistics and research, internal consistency is typically a measure based on the correlations between different items on the same test (or the same subscale on a larger test). It measures whether several items that propose to measure the same general construct produce similar scores. Cronbach's $\alpha$ is used to measure the internal consistency of the data in this research. It was first named alpha by Lee Cronbach in 1951, and it is widely used in the social sciences, business, nursing and other disciplines.

Cronbach's $\alpha$ is defined as:

$$
\alpha=\frac{K}{K-1}\left(1-\frac{\sum S_{\mathrm{i}}^{2}}{S_{T}^{2}}\right)
$$

Where $K$ is the number of the components ( $K$-items), $S_{T}^{2}$ is the variance of the observed total test scores, and $S_{\mathrm{i}}^{2}$ is the variance of component $i$ for the current samples

The Cronbach's $\alpha$ is 0.6521 in this research which means that the internal consistency is acceptable.

\subsection{Fisher's Exact Test}

The system related factors are taken for example to show the Prsher's exact test, and the hypotheses and the Fisher's exact test process related with system related factors are as follows:

Hypothesis-1(a): Efficiency $\left(\mathrm{C}_{1}\right)$ has a significant influence on online service satisfaction Hypothesis-1(b): Efficiency $\left(\mathrm{C}_{1}\right)$ has a lower influence on online service satisfaction

Table 7. Online Service Satisfaction Efficiency $\left(C_{1}\right)$ Impact Analysis

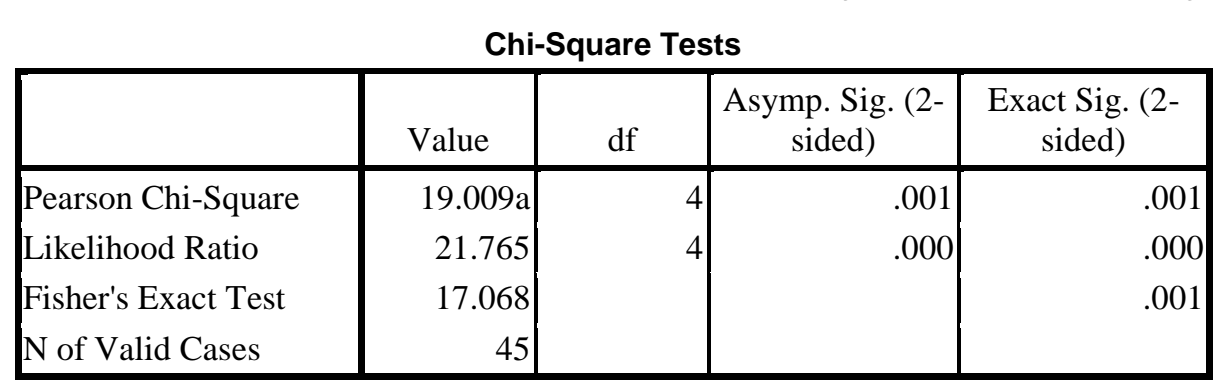

a. 5 cells $(55.6 \%)$ have expected count less than 5 . The minimum expected count is 2.67 .

As shown in Table 7,the value of Fisher's Exact Test is 17.068,Exact Sig.(2-sided) is 0.001 , which is lower than 0.05 , therefore Hypothesis-1(a) is accepted with significant level of $5 \%$, which means that efficiency has a significant influence on online service satisfaction.

Hypothesis-2(a): Ease of navigation $\left(\mathrm{C}_{2}\right)$ has a significant influence on online service satisfaction

Hypothesis-2(b): Ease of navigation $\left(\mathrm{C}_{2}\right)$ has a lower influence on online service satisfaction 


\section{Table 8. Online Service Satisfaction* Ease of Navigation $\left(C_{2}\right)$ Impact Analysis}

\section{Chi-Square Tests}

\begin{tabular}{|c|c|c|c|c|}
\hline & Value & df & $\begin{array}{l}\text { Asymp. Sig. (2- } \\
\text { sided) }\end{array}$ & $\begin{array}{l}\text { Exact Sig. (2- } \\
\text { sided) }\end{array}$ \\
\hline Pearson Chi-Square & $14.849 a$ & 6 & .021 & .014 \\
\hline Likelihood Ratio & 17.231 & 6 & .008 & .012 \\
\hline Fisher's Exact Test & 13.223 & & & .016 \\
\hline $\mathrm{N}$ of Valid Cases & 45 & & & \\
\hline
\end{tabular}

a. 8 cells $(66.7 \%)$ have expected count less than 5 . The minimum expected count is .53

As shown in Table 8, the value of Fisher's Exact Test is 13.223,Exact Sig.(2-sided) is 0.016 ,lower than 0.05 ,therefore Hypothesis-2(a)is accepted with significant level of $5 \%$, which means that ease of navigation $\left(\mathrm{C}_{2}\right)$ has a lower influênce on e-service satisfaction.

Hypothesis-3(a): Flexibility $\left(\mathrm{C}_{3}\right)$ has a significant influence on online service satisfaction

Hypothesis-3(b): Flexibility $\left(\mathrm{C}_{3}\right)$ has a lower influence on online service satisfaction

Table 9. Online Service Satisfaction Flexibility $\left(\mathrm{C}_{3}\right)$ Impact Analysis Chi-Square Tests

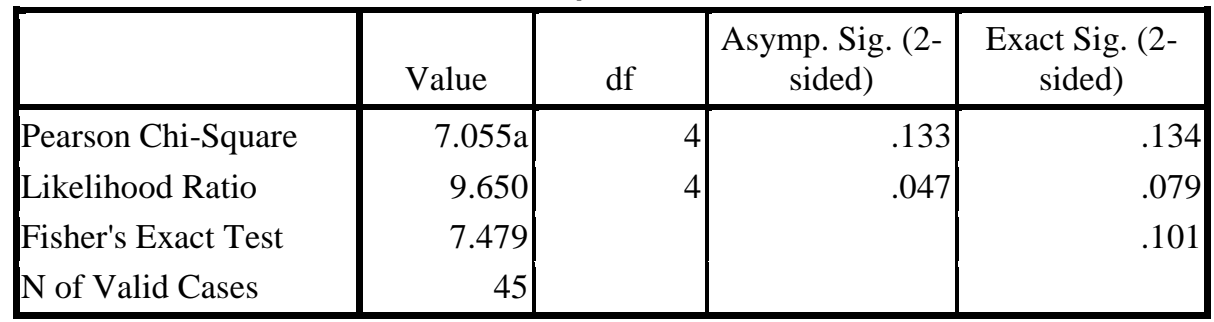

a. 4 cells $(44.4 \%)$ have expected count less than 5 . The minimum expected count is 2.93 .

As shown in Table 9, the value of Fisher's Exact Test is 7.479,Exact Sig.(2-sided) is 0.101 ,greater than 0.05 , therefore Hypothesis-3(a)is refused.

Hypothesis-4(a): Reliability $\left(\mathrm{C}_{4}\right)$ has a significant influence on online service satisfaction

Hypothesis-4(b): Reliability $\left(\mathrm{C}_{4}\right)$ has a lower influence on online service satisfaction

\begin{tabular}{|c|c|c|c|c|}
\hline \multicolumn{5}{|c|}{ Chi-Square Tests } \\
\hline D & Value & $\mathrm{df}$ & $\begin{array}{l}\text { Asymp. Sig. (2- } \\
\text { sided) }\end{array}$ & $\begin{array}{l}\text { Exact Sig. (2- } \\
\text { sided) }\end{array}$ \\
\hline Pearson Chi-Square & $13.668 \mathrm{a}$ & 4 & .008 & .007 \\
\hline Likelihood Ratio & 15.280 & 4 & .004 & .008 \\
\hline Fisher's Exact Test & 12.444 & & & .009 \\
\hline $\mathrm{N}$ of Valid Cases & 45 & & & \\
\hline
\end{tabular}

a. 5 cells $(55.6 \%)$ have expected count less than 5 . The minimum expected count is 2.40 . 
As shown in Table 10,the value of Fisher's Exact Test is 12.444,Exact Sig.(2-sided) is 0.009, lower than 0.05,therefore Hypothesis-4(a)is accepted.

Hypothesis-5(a): Price knowledge $\left(\mathrm{C}_{5}\right)$ has a significant influence on online service satisfaction

Hypothesis-5(b): Price knowledge $\left(\mathrm{C}_{5}\right)$ has a lower influence on online service satisfaction

Table 11. Online Service Satisfaction * Price Knowledge $\left(C_{5}\right)$ Impact Analysis

Chi-Square Tests

\begin{tabular}{|l|l|l|l|l|}
\hline & Value & df & $\begin{array}{l}\text { Asymp. Sig. (2- } \\
\text { sided) }\end{array}$ & $\begin{array}{l}\text { Exact Sig. (2- } \\
\text { sided) }\end{array}$ \\
\hline Pearson Chi-Square & $14.583 \mathrm{a}$ & 8 & .068 & .032 \\
Likelihood Ratio & 15.299 & 8 & .054 & .047 \\
Fisher's Exact Test & 12.749 & & 040 \\
$\mathrm{~N}$ of Valid Cases & 45 & & &. \\
\hline
\end{tabular}

a. 12 cells $(80.0 \%)$ have expected count less than 5. The minimum expected count is .27 .

As shown in Table 11, the value of Fisher's Exact Test is 12.749, Exact Sig.(2-sided) is 0.40,greater than 0.05, therefore Hypothesis-5(a)is rejected with significant level of 5\%.

Hypothesis-6(a): Aesthetics $\left(\mathrm{C}_{6}\right)$ has resionificant influence on online service satisfaction

Hypothesis-6(b): Aesthetics $\left(\mathrm{C}_{6}\right)$ has a lower influence on online service satisfaction

Table 12. Online Service Satisfaction* Aesthetics $\left(C_{6}\right)$ Impact Analysis

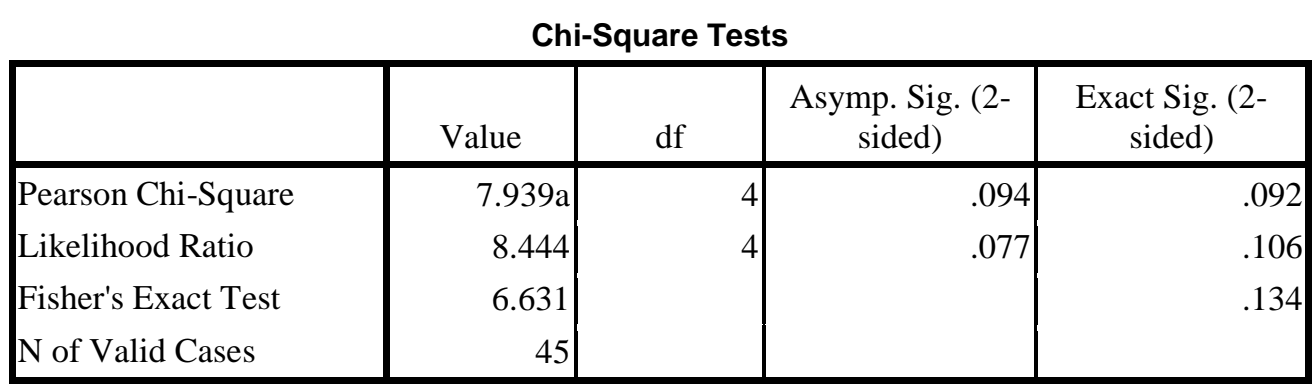

a. 5 cells $(55.6 \%)$ have expected count less than 5 . The minimum expected count is 1.60 .

As shown in Table 12, the value of Fisher's Exact Test is 6.631, Exact Sig.(2-sided) is 0.134 ,greater than 0.05 ,therefore Hypothesis-6(a)is rejected with significant level of 5\%.

A)pothesis-7(a): Personalization $\left(\mathrm{C}_{7}\right)$ has a significant influence on online service satisfaction

Hypothesis-7(b): Personalization $\left(\mathrm{C}_{7}\right)$ has a lower influence on online service satisfaction 


\section{Table 13. Online Service Satisfaction * Personalization $\left(C_{7}\right)$ Impact Analysis}

\section{Chi-Square Tests}

\begin{tabular}{|c|c|c|c|c|}
\hline & Value & $\mathrm{df}$ & $\begin{array}{l}\text { Asymp. Sig. (2- } \\
\text { sided) }\end{array}$ & $\begin{array}{l}\text { Exact Sig. (2- } \\
\quad \text { sided) }\end{array}$ \\
\hline Pearson Chi-Square & $18.289 \mathrm{a}$ & 6 & .006 & .002 \\
\hline Likelihood Ratio & 21.148 & 6 & .002 & .001 \\
\hline Fisher's Exact Test & 16.569 & & & .002 \\
\hline $\mathrm{N}$ of Valid Cases & 45 & & & \\
\hline
\end{tabular}

a. 8 cells $(66.7 \%)$ have expected count less than 5 . The minimum expected count is .27

As shown in Table 13, the value of Fisher's Exact Test is 16.569, Exact Sig.(2-sided) is 0.002 ,lower than 0.05, therefore Hypothesis-7(a)is accepted with significant level of $5 \%$.

Hypothesis-8(a): Ownership conditions $\left(\mathrm{C}_{8}\right)$ has a significant influence on online service satisfaction

Hypothesis-8(b): Ownership conditions $\left(\mathrm{C}_{8}\right)$ has a lewer influence on online service satisfaction

Table 14. Online Service Satisfaction Ownershipoonditions $\left(\mathrm{C}_{8}\right)$ Impact Analysis

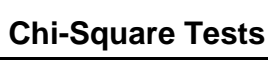

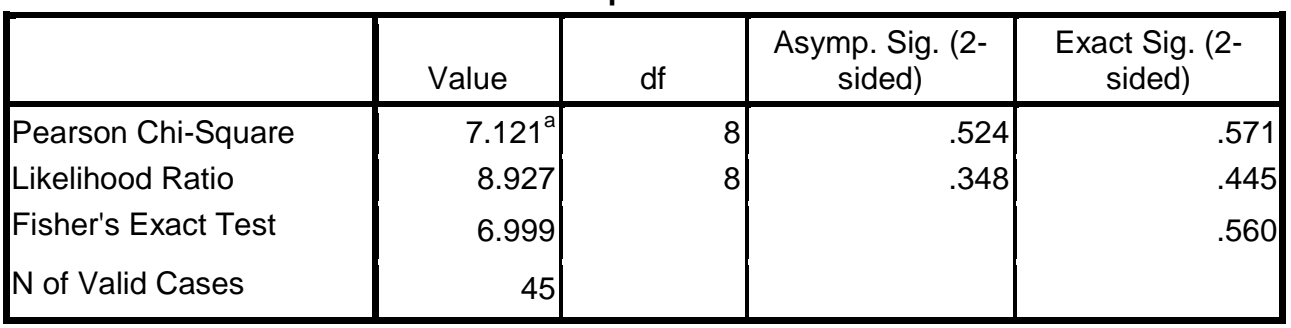

a. 13 cells $(86.7 \%)$ have expected count less than 5 . The minimum expected count is .27 .

As shown in Table 14, the value of Fisher's Exact Test is 6.999, Exact Sig.(2-sided) is 0.560 ,greater than 0.05 , therefore Hypothesis-8(a)is refused with significant level of $5 \%$.

Hypothesis-9( $a)$. Ease of use $\left(\mathrm{C}_{9}\right)$ has a significant influence on online service satisfaction Hypothesis $9(b)$ : Ease of use $\left(\mathrm{C}_{9}\right)$ has a lower influence on online service satisfaction

\section{Table 15 Online Service Satisfaction * Ease of Use $\left(C_{9}\right)$ Impact Analysis}

\begin{tabular}{|c|c|c|c|c|}
\hline \multicolumn{5}{|c|}{ Chi-Square Tests } \\
\hline & Value & $\mathrm{df}$ & $\begin{array}{l}\text { Asymp. Sig. (2- } \\
\text { sided) }\end{array}$ & $\begin{array}{l}\text { Exact Sig. (2- } \\
\text { sided) }\end{array}$ \\
\hline Pearson Chi-Square & $15.949 a$ & 4 & .003 & .002 \\
\hline Likelihood Ratio & 15.574 & 4 & .004 & .006 \\
\hline Fisher's Exact Test & 13.405 & & & .004 \\
\hline N of Valid Cases & 45 & & & \\
\hline
\end{tabular}

a. 5 cells $(55.6 \%)$ have expected count less than 5 . The minimum expected count is 1.33 . 
As shown in Table 15, the value of Fisher's Exact Test is 13.405, Exact Sig.(2-sided) is 0.004 ,lower than 0.05,therefore Hypothesis-9(a) is accepted with significant level of 5\%.

Hypothesis-10(a): Speed $\left(\mathrm{C}_{10}\right)$ has a significant influence on online service satisfaction

Hypothesis-10(b): Speed $\left(\mathrm{C}_{10}\right)$ has a lower influence on online service satisfaction

Table 16. Online Service Satisfaction * Speed $\left(C_{10}\right)$ Impact Analysis

\begin{tabular}{|c|c|c|c|c|}
\hline \multicolumn{5}{|c|}{ Chi-Square Tests } \\
\hline & Value & df & $\begin{array}{l}\text { Asymp. Sig. (2- } \\
\text { sided) }\end{array}$ & $\begin{array}{l}\text { Exact Sig. (2- } \\
\text { sided) }\end{array}$ \\
\hline $\begin{array}{l}\text { Pearson Chi-Square } \\
\text { Likelihood Ratio } \\
\text { Fisher's Exact Test } \\
\mathrm{N} \text { of Valid Cases }\end{array}$ & $\begin{array}{r}22.068 a \\
25.062 \\
20.519 \\
45\end{array}$ & $\begin{array}{l}8 \\
8\end{array}$ & $\begin{array}{l}.005 \\
.002\end{array}$ & \\
\hline
\end{tabular}

a. 11 cells $(73.3 \%)$ have expected count less than 5 . The minimum expected count is .27.

As shown in Table 16, the value of Fisher's Exact Test is 20.519, Exact Sig.(2-sided) is 0.001 ,lower than 0.05 ,therefore Hypothesis-10(a) is accepted with significant level of $5 \%$.

\section{Conclusions}

This paper is an attempt to identify the key factors affecting the online service quality in China. The primary data for this research arecollected through a questionnaire, and Fisher's exact test is applied to identify the criteria of online service quality impact analysis. The results could be the guideline for the e-commerce companies in terms of improving their service.

According to the results of the analysis, the main factors affecting online service satisfaction are shown in Cable 17:

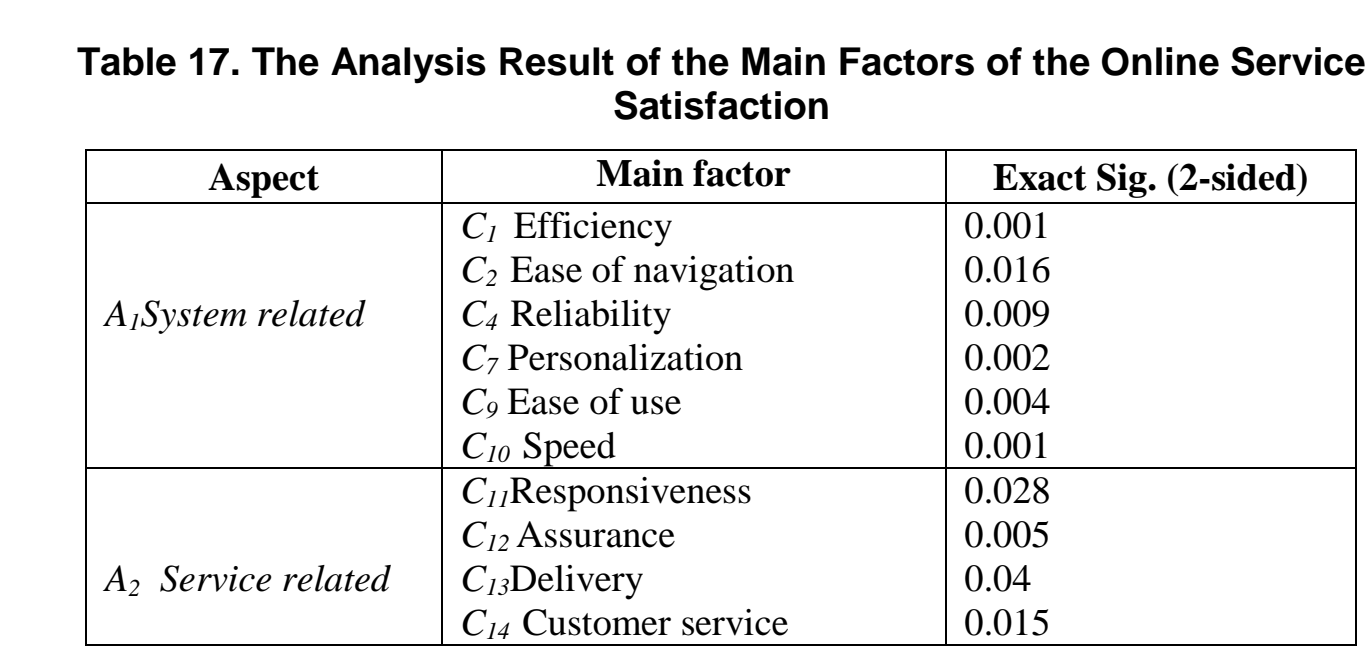

Based on the results of this research, our recommendations for improving the online service of the e-commerce companies are: (1) improving the efficiency, reliability and speed of the respond; (2) shortening the delivery time; and (3) enriching personalization and customer service. 


\section{Acknowledgements}

Social sciences planning project of He Nan Province, 2012. <<The research on the development trend of E-Business about Small and Medium-sized enterprise of HeNan under Low Carbon Economy > (Project grant no.:2012BJJ006); Soft science project of Science and Technology Agency of HeNan Province, 2013. << The Research on Developing Situation and Evaluating of HeNan Agricultural website >> (Project grant no.:132400410438).

\section{References}

[1] A. M. Aladwani and P. C. Palvia, "Developing and validating an instrument for measuring user-perceived web quality", Information and Management, vol. 39, no. 6, (2002), pp. 467-476.

[2] S. J. Barnes and R. T. Vidgen, "An integrative approach to the assessment of e-commerce quality”, Journal of Electronic Commerce Research, vol. 3, no. 3, (2002), pp. 114-27.

[3] H. H. Bauer, T. Falk and M. Hammerschmidt, "E Trans Qual:a transaction process-based approach for capturing service quality in online shopping", Journal of Business Research, vol. 59, (2006), pp 866-875.

[4] S. Cai and M. Jun, "Internetusers'perceptions of online service quality; a comparison of online buyers and information searchers", Managing Service Quality, vol. 13, no. 6, (2003), pp»504-519.

[5] J. E. Collier and C. C. Bienstock, "Measuring service quality in e-retailing", Journal of Service Research, vol. 8, no. 3, (2006), pp. 260-275.

[6] E. Cristobal, C. Flavian and M. Guinaliu, "Perceived e-se vice quality (PeSQ): measurement validation and effects on consumer satisfaction and website loyalty", Managing Service Quality, vol. 17, no. 3, (2007), pp. 317-340.

[7] D. X. Ding, J. P. Hu and L. O. Sheng, "E-SELFQUAL. a scale for neasuring online self-service quality", Journal of Business Research, vol. 64, (2011), pp. $508-515$.

[8] M. Fassnacht and I. Koese, "Quality of electronic services: conceptualizing and testing a hierarchical model", Journal of Service Research, vol. 9, no. 1, (2006), pp. 19-37

[9] R. A. Fisher, "On the interpretation of $\chi 2$ from contingency tables, and the calculation of P", Journal of the Royal Statistical Society, vol. 85, no. 1,pp. 87-94.

[10] J. E. Francis and L. White, "PIRQUA1- a scale for measuring customer expectations and perceptions of quality in Internet retailing", Proceedings of the Winter Educator's Conference, AMA, Chicago, IL: American Marketing Association, (2002), pp.468-443.

[11] D. Gefen, "Customer loyalyne-commerce" Journal of the Association for Information Systems, vol. 3, (2002), pp. 27-51.

[12] S. Gounaris and S Dimitriadis, "Assessing service quality on the web: evidence from business-to-consumer portals", Journal of Services Marketing, vol 17, no. 4-5, (2003), pp. 529-548.

[13] Ha, S. \& L. Stoel, “Consumer e-shopping acceptance: antecedents in a technology acceptance model", Journal of Business Research vol, 62, (2009), pp. 565-571.

[14] C. I. Ho and Y.L. Lee, "The development of an e-travel service quality scale", Tourism Management, vol. 26, (2007), pp. 1434-1449

[15] B. B. Holloway and S E, Beatty, "Service failure in online retailing: arecovery opportunity", Journal of Service Research, vol. 6, no. 1, (2003), pp. 92-105.

[16] M. Howard and Q Worboys, "Self-service - a contradiction in terms or customer-led choice?", Journal Consume Behavior, vol. 2, no. 4, (2003), pp. 382-92.

[17] S. H. Hsu "Developing an index for online customer satisfaction: adaptation of American customer satisfaction index", Expert Systems with Applications, vol. 34, (2008), pp. 3033-3042.

[18] Y. Hwang and D. J. Kim, "Customer self-service systems: the effects of perceived web quality with service contents on enjoyment, anxiety, ande-trust”, Decision Support Systems, vol. 43, (2007), pp. 746-760.

[19] E. E. Ibrahim, M. Joseph and K. I. N. Ibeh, "Customers'perception of electronic service delivery in the UK retail banking sector", International Journal of Bank Marketing, vol. 24, no. 7, (2006), pp. 475-493.

[20] S. Janda, P. J. Trocchia and K. P. Gwinner, "Consumer perceptions of Internet retail service quality", International Journal of Service Industry Management, vol. 13, no. 5, (2002), pp. 412-431.

[21] M. Jun, Z. Yang and D. Kim, "Customers' perceptions of online retailing service quality and their satisfaction", International Journal of Quality and Reliability Management, vol. 21, no. 8, (2004), pp. 817840.

[22] S. Kim and L. Stoel, "Apparel retailers: website quality dimensions and satisfaction”, Journal of Retailing and Consumer Services, vol. 11, no. 2, (2004), pp. 109-117.

[23] G. Lee and H. Lin, "Customer perceptions of e-service quality in onlines hopping", International Journal of Retail and Distribution Management, vol. 33, no. 2, (2005), pp. 161-176. 
[24] E. T. Loiacono, R. T. Watson and D. L. Hoodhue, "WEBQUAL:measure of website quality", Marketing Educators Conference: Marketing Theory and Applications, vol. 13, (2002), pp. 432-437.

[25] R. R. Nelson, P. A. Todd and B. H. Wixom, "Antecedents of information and system quality: an empirical examination within the context of data warehousing", Journal of Management Information Systerm, vol. 21, no. 4, (2005), pp. 199-235.

[26] A. Parasuraman, V. A. Zeithaml and A. Malhotra, "E-S-Qual: a multiple-item scale for assessing electronic service quality", Journal of Service Research, vol. 7, no. 3, (2005), pp. 213-233.

[27] C. Ranganathan and S. Ganapathy, "Key dimensions of business-to-consumer web sites", Information and Management, vol. 39, (2002), pp. 457-465.

[28] J. Santos, "E-service quality: a model of virtual service quality dimension", Managing Service Quality, vol. 13, no. 3, (2003), pp. 233-246.

[29] A. Serkan, A. Eda and A. Safak, "Re-assessment of E-S-Qual and E-RecS-Qual in a pure service setting", Journal of Business Research, vol. 63, no. 3, pp. 232-240.

[30] C. Sohn and S. K. Tadisina, "Development of e-service quality measure for internet-based financial institutions", Total Quality Management and Business Excellence, vol. 19, no. 9, (2008), pp. 903-918.

[31] Y. Wang, D. M. Hernandez and S. M. Minor, "Web aesthetics effects on perceived online service quahty and satisfaction in an e-tail environment: the moderating role of purchase task", Journal of Busines Research, vol. 63, (2010), pp. 935-942.

[32] B. H. Wixom and P. A. Todd, "A theoretical integration of user satisfaction and technology acceptance", Information System Research, vol. 16, no. 1, (2005), pp. 85-102.

[33] M. Wolfinbarger and M. C. Gilly, "ETailQ: dimensionalizing measuring and predicting retail quality", Journal of Retailing, vol. 79, no. 3, (2003), pp. 183-198.

[34] Z. Yang and M. Jun, "Consumer perception of e-service quality: form purchaser and non purchaser perspectives", Journal of Business Strategies, vol. 19, no. 1, (2002), pp. 19-41

[35] Z. Yang, "Development and validation of an instrament to measure user perceived service quality of information presenting Web portals", Information and Management, vol.42, (2005), pp. 575-589.

[36] B. Yoo and N. Donthu, "Developing a scale to measure the percerved quality of Internet shopping sites (SITEQUAL)", Quarterly Journal of Electronic Commerce, vol.2, no. 1, (2001), pp. 31-47.

[37] V. A. Zeithaml, A. Parasuraman and A. Malhotra, "E-service quality: definition, dimensions and conceptual model”, Working Paper, Marketing Science Institute, Cambridge, MA, (2000).

[38] V. A. Zeithaml, A. Parasuraman and A. Malhotra "Service quality delivery through websites: acritical review of extant knowledge", Journal of the Acaderny of Marketing Science, vol. 30, no. 4, (2002), pp. 362375.

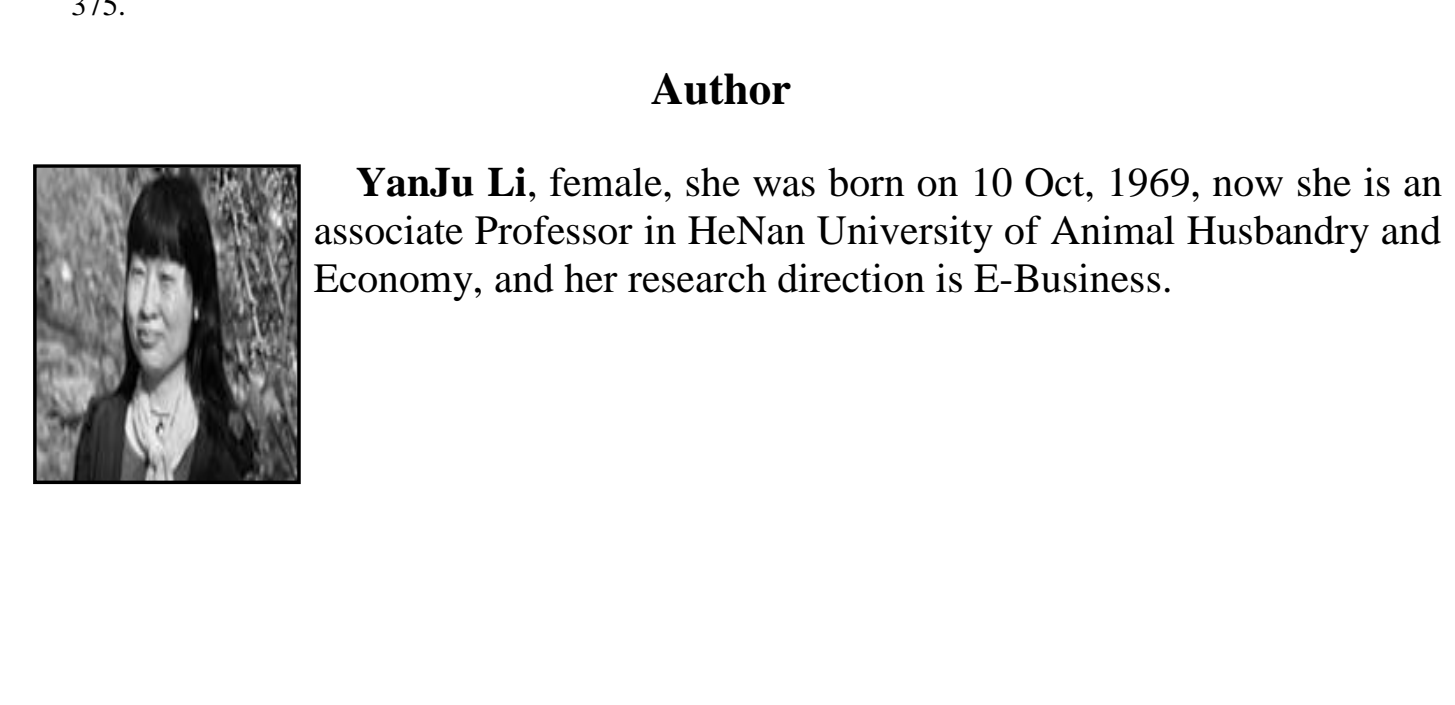


International Journal of Smart Home

Vol.8, No.3 (2014)

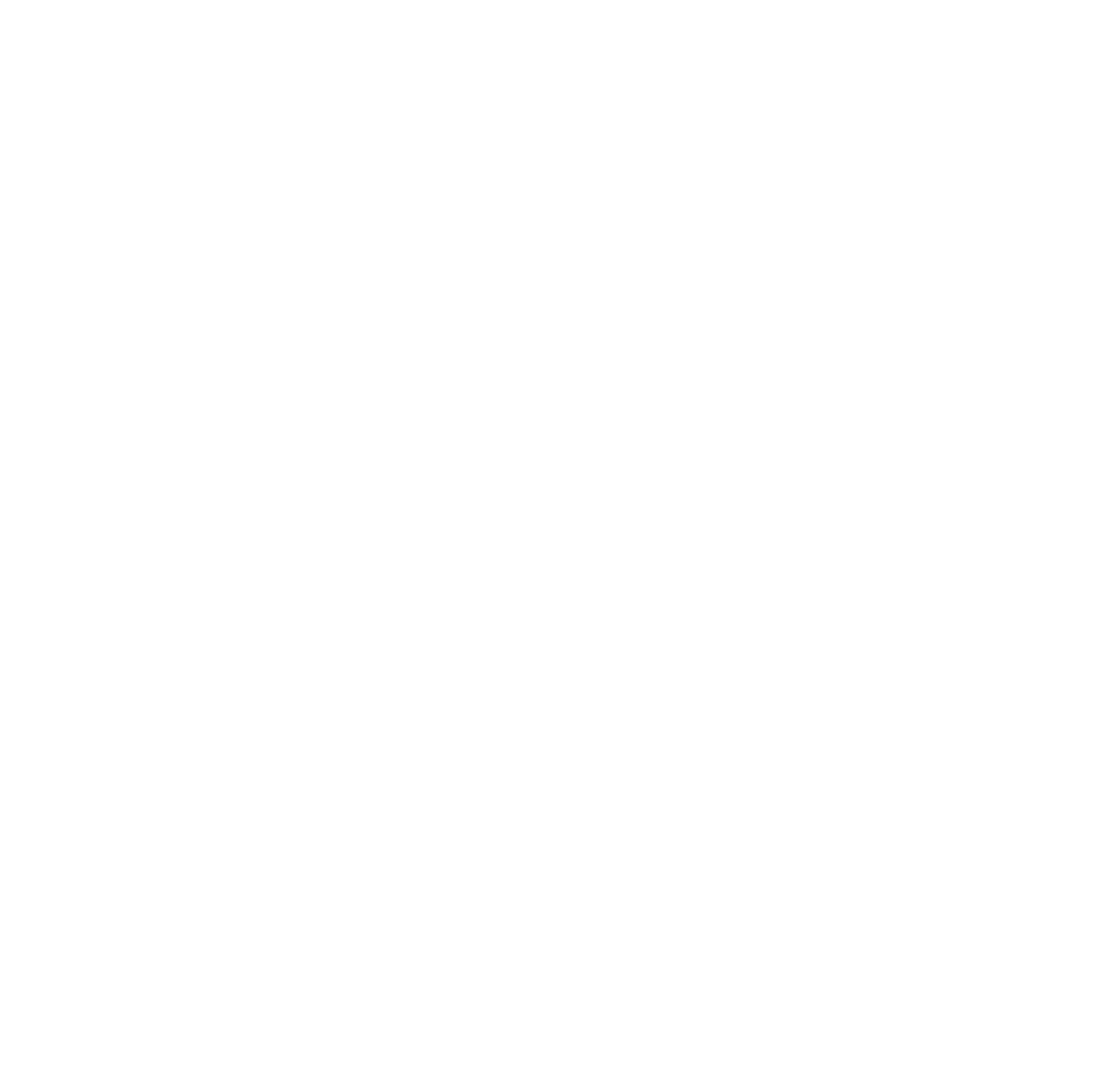

